\title{
The Impact of External Audit in Corporate Financial Distress
}

\author{
Siti Noor Khikmah ${ }^{1,2 *}$, Abdul Rohman ${ }^{3}$, Indira Januarti ${ }^{3}$ \\ ${ }^{1}$ Doctoral Program of Economic and Accounting, Universitas Diponegoro, Semarang, Indonesia \\ ${ }^{2}$ Department of Economics and Business, Universitas Muhammadiyah Magelang, Magelang, Indonesia \\ ${ }^{3}$ Department of Economics and Business, Universitas Diponegoro Semarang, Indonesia \\ ${ }^{*}$ Corresponding author. Email: noorkhikmah@ummgl.ac.id
}

\begin{abstract}
This paper is aimed at examining and analysing the impact of external audit on financial distress in Indonesian manufacturing companies. In addition, the samples used include data from manufacturing companies within the period 2014-2017, using purposive sampling method. A total of 128 companies were evaluated using panel data regression analysis, and the results showed the effect of going concern opinion, auditor switching and audit reputation on financial distress, although audit delay had no influence. Therefore, the implication of this research was to investigate the financial distress of companies in the capital market, especially in relation to the role of external audit.
\end{abstract}

Keywords: financial distress, going concern opinion, auditor switching, audit reputation, audit delay

\section{INTRODUCTION}

Bankruptcy is a condition characterized by a company's inability to operate properly as a result of severe financial distress, and the corporate is dreaded by both company owners and employees. A bankruptcy or financial failure occurs on instances where the current amount of liabilities exceeds the fair value of assets [1]. Furthermore, it is known to adversely affect the world economy [2], characterized by a prolonged and continuous decline in the financial condition of company's financial distress, [3].

Based on the phenomenon covered by Bisnis.com, seven Indonesian companies experienced financial distress throughout 2017, encompassing 1). PT Megalestari Unggul, declared bankrupt by the Central Jakarta Commercial Court on February 22, 2017, and was proven to owe IDR 376.84 billion to PT Senja Imaji Prisma. 2). PT Citra Maharlika Nusantara Corpora Tbk, on April 27, 2017, which was based on the peace proposal rejected by the majority of creditors. 3). PT Multicon Indrajaya Termina, known to have been successfully sold by three foreign investment companies, including Asean China Investments Fund II LP, UVM Venture Investments LP and SACLP Investments Limited on 4 May 2017. 4). The case with PT Kimas Sentosa occurred on 15 June 2016, with debts valued at IDR 758.40 billion. 5). A subsidiary of PT Sugih Energy Tbk was indebted to 47 creditors, totalling IDR 117.65 billion. 6). PT Asia Paper Mills was declared bankrupt by the Central Jakarta Commercial Court on August 7, 2017, with a total debt of IDR 568 billion. 7). PT Dwi Aneka Jaya Kemasindo Tbk (DAJK), a card and paper packaging company that officially attained bankruptcy on November 22, 2017, with up to IDR 1.1 trillion worth of debt.

Various researches on financial distress have been performed, which requires investigating the relationship between 1). internal factors, encompassing financial ratios, lack of management experience, as well as knowledge in using assets and liabilities effectively and 2). the external influences, e.g., inflation and investment inflation, the tax and legal system, depreciation of foreign currencies, and other reasons [4], as the cause of bankruptcy to a company. Inekwe et. al. examined the risk of ex ante increasing GDP growth by up to $9 \%$, showing greater contraction in exports and investment. Furthermore, there is a substantial negative impact of investment intensity and debt financing on companies experiencing financial distress during the 2009 2010 global financial crisis [5]. Hence, leverage factors negatively impact on financial health, [6].

A number of external audit factors that affect financial distress have not been studied in Indonesia, as the focus of previous research were limited to on-going concern opinions, auditor switching [7], audit fees and industry specialist inspections [8]. The external auditors play an important role in ensuring financial reporting, as its effective conduction provides the necessary guarantees, including assistance in the demotion of misstatement and discretionary accruals [9], [10]. This is also characterized by information and insurance for the benefit of investors and bondholders. As an information provider, they independently verify the financial statements prepared by the manager, and as an insurance provider, auditors are also likely to be sued in terms of security laws, as they are liable to provide compensation to the users of financial statements for wrong audits [11].

The results of the process are to provide opinions to clients, needed to increase the level of business confidence. Meanwhile, the increasing number of bankruptcies caused by global economic conditions is very frightening for stakeholders, thus most tend to rely on auditors' opinions as a guide. Despite the fact that the auditor is not responsible for predicting bankruptcy and issuing a going concern opinion, investors expect warnings against financial failures. This condition has a positive and significant effect on financial distress[12], while [13] reported the direct connection between the limitation of opinions that meet the 
requirements with the client's subsequent financial distress. This issuance ensues as a result of changes in reporting decisions, and is not solely related to differences in client characteristics [14],[15]. Therefore, the abilities that meet the requirements tend to serve as an early warning signal of financial distress in further evaluation.

Auditor switching is another external factor. Schwartz and Menon stated the enhanced tendency to perform auditor changes in companies that deteriorate than those that are sound financially. Specifically, higher difficulties are observed to be significantly correlated with intentional changes, as companies with a higher likelihood of being exposed to distress possess the incentive to negatively suppress the information contained in financial situations. Being provided with the monitoring of external auditors, users of statements naturally tend to attribute the prescribed opinion. There is a company's involvement in the act of changing auditors or management of earnings, in an ongoing effort to cover up the deteriorating financial conditions, and tends to emerge from bankruptcy[16].

This study extends from previous research, in an attempt to empirically examine auditor changes, and the probability of client financial pressure. Furthermore, it also investigates external audit factors, which ensue in the form of going concern opinion, auditor switching and others that have not been studied, encompassing their reputation and possible delay, as a research material on financial distress. These companies that have been audited by those with good reputation are often spared from distress, as they are of effective conduct, and are also able to ensure reliability of statements that accurately represent the company's performance and financial position [17]. Therefore, the provision $\mathrm{f}$ reports beyond the audit date are assumed to possess financial distress, based on the fat that there are numerous items to be examined.

The hypothesis proposed in this study is $\mathrm{H} 1$ : going concern opinion has a positive effect on financial distress, $\mathrm{H} 2$ : auditor switching has a positive effect on financial distress, H3: auditor reputation has a negative effect on financial distress and H4: audit delay has a positive effect on financial distress. Therefore, the purpose of this study is to examine and analyse the relationship between external audit factors and financial distress in manufacturing companies within the 2014-2017 period.

\section{METHODS}

The population of this research encompasses manufacturing companies listed on the Indonesia Stock Exchange (IDX) between 2014 - 2017. In addition, purposive sampling techniques were used to select those that comply with the research criteria, encompassing manufacturing companies that: 1). have been listed on the Indonesia Stock Exchange (BEI) and have submitted annual financial reports for the year 2014-2017. 2). not delisted during the study period. 3). experienced profits during the research period in a row. 4). submit consecutive auditor reports. Furthermore, the sample of this research included 128 companies within the observation of 2014 to 2017 data, which were evaluated using descriptive statistics and panel data regression.

The dependent variable is financial distress, is the long-term debt divided by share capital. The independent variable are going concern opinion, auditor switching, auditor reputation and audit delay. The going concern opinion variable is the dummy variable, which assumes the value of 1 if the firm accepts going concern opinion and 0 otherwise. The auditor switching variable is a dummy for auditor switching, taking the value 1 where there is a change in the incumbent auditing firm during the accounting cycle, otherwise coded 0 . The auditor reputation variable is the a dummy for auditor reputation, taking the value 1 on instances where the big-four audit firm and 0 depicts otherwise cases. The audit delay variable for the audit delay is the value for the number of days between the closing date of the book and the date for independent auditor's report is published.

\section{RESULTS AND DISCUSSION}

In this chapter, the researcher would like to describe the research findings and discussion. Research finding presented data which was collected by interview and observation. Then, research discussion is the explanation about data as the result of interview and observation. There are some sub-chapters that involve interview result, observation result, and research discussion.

\subsection{Descriptive Statistic}

The result of descriptive statistical analysis showed in Table 1 .

Table 1 Descriptive Statistic

\begin{tabular}{|c|c|c|c|c|}
\hline Variable & Mean & $\begin{array}{c}\text { Standard } \\
\text { dev. }\end{array}$ & Min. & Max. \\
\hline Going Concern & 0,578 & 0,496 & 0,00 & 1,00 \\
\hline Auditor Switc & 0,244 & 0,430 & 0,00 & 1,00 \\
Audit Rep & 0,469 & 0,501 & 0,00 & 1,00 \\
\hline Audit Delay & 80,289 & 6,880 & 61,00 & 99,00 \\
Financial Distress & $-1,562$ & 1,000 & $-1,07$ & 4,04 \\
\hline
\end{tabular}

Source: Primary Data, 2018

This table shows the descriptive statistics of the variables included in model, and going concern was measured as the dummy variable, which assumes the value of 1 where the firm accepts and 0 otherwise. Furthermore, auditor switching measured with dummy variable, assumes the value of 1 where the firm changes auditors and 0 otherwise, 
while reputation was measured with dummy that assumes the value 1 when the big-four audit firm and 0 otherwise. In addition, audit delay was measured in number of days between the book closing date and the time of publishing the independent auditor's report, thus, financial distress is a calculation of Long-term debt divided by share capital.

Based on table 1 descriptive statistic shows the propensity for the average of the 128 companies being sampled to obtain going concern opinion. In addition, the value for auditor switching variable shows the likelihood for most companies to replace auditors, while the average value on reputation illustrates that some used KAP big for. Regarding audit delay, a majority tend to take a long time in completing the audit process, and the average value of financial distress shows that most companies are experiencing financial distress.

\subsection{Regression Analysis}

The result of regression analysis is shown in table 2

Table 2 Regression Analysis

\begin{tabular}{|l|r|r|r|r|}
\hline Variable & $\begin{array}{c}\text { Estimated } \\
\text { Coefficients }\end{array}$ & $\begin{array}{c}\text { Standard } \\
\text { error }\end{array}$ & $\boldsymbol{t}$-statistic & $\boldsymbol{p}$-value \\
\hline Intercept & $-1,154$ & 0,855 & $-1,817$ & 0,072 \\
\hline GC & 0,354 & 0,145 & 2,444 & 0,016 \\
AS & 0,286 & 0,168 & 1,697 & $0,096^{* *}$ \\
\hline AR & 1,236 & 0,143 & 8,651 & 0,000 \\
\hline AD & 0,009 & 0,010 & 0,846 & 0,399 \\
\hline Model & \multicolumn{5}{c}{0,371} \\
\hline Adj R2 & 19,698 \\
\hline F Statistic & 0,000 \\
\hline Sig F & 127 \\
\hline N
\end{tabular}

Source: Primary Data, 2018

Note: * denote two-tailed statistical significance levels at 5\%, respectively. T-statistics and p-values are given in brackets and square brackets, respectively.

** Two-tailed statistical significance levels at $10 \%$, respectively

Based on the results in table 2, the regression coefficient for going concern opinion variables shows a $p$ value of 0.016 , observed to be smaller than the level of statistical significance 0.05 , subsequently supporting the H1 stipulating its positive influence on financial distress. Therefore, these companies tend to provide early warning about potential problems for stakeholders, provided with the external auditor's monitoring function naturally associates the opinion with the audited financial health, as well as the emergence of a bankruptcy.

The role of going concern opinion is to remind stakeholders of the potential effect of financial distress, as determined by SAS No. 34 and No. 59, which stipulates the need for investors and creditors that receive signals to take action in an attempt to reduce potential losses. Therefore, issuing it from the outset enables the effectivity of alternative plans (for example, there are ample assets), and it is also positively related to bankruptcy. The results obtained support the research of [7] which reported the correlation of going concern opinion with financial distress, and it does not support the study by [18], stipulating the tendency for auditors that face the likelihood of losing clients to issue unmodified audit reports. The propensity for those that emerge from strategic considerations to choose the nonissuance of opinions that meet the requirements of continuity, although auditors most times believe in the likelihood of client bankruptcy [19].

The second result shows the existence of a positive regression coefficient with a value of 0.096 , which is smaller than the significance of 0.1 , therefore $\mathrm{H} 2$ is accepted, this indicates the positive effect of auditor switching on financial distress. Schwartz and Menon (1985) stated the attempt of auditor turnover by management to suppress negative information about a company. Hence, the change of auditor is related to the auditor / client strategic behaviour, which plays a role in predicting the clients' propensity to experience financial distress. Furthermore, these companies subsequently have a higher probability of causing financial distress, and the characteristics more often occurs in those that deteriorate financially than otherwise, [20].

Lack of success in suppressing information that does not benefit the auditor causes the adoption of changes, prior to bankruptcy. Conversely, companies that do not embark on a replacement strategy seem to enjoy greater success in the aspect of suppressing negative income and increasing information [21].

The third result obtained shows a positive regression coefficient for the auditor's reputation, with a $\mathrm{p}$ value of 0.00 , which is smaller than the significance level of 0.05 . Despite the significance H3 is not supported, as the decrease in the financial distress decreases with the effect of higher reputation. Based on the company sample data, the majority experience financial distress, therefore selecting a good auditor reputation tends to worsen the outcome. Ideally, companies audition by larger auditors do not promote bankruptcy, based on the provision of credibility to the financial statements, creating allowance for benefits from lower capital and debt costs.

In the fourth study, the regression coefficient for audit delay was positive at 0.399 , which is greater than the statistical significance of 0.05 and 0.1 , hence H4 was not accepted, and the results shows the inability for audit delay to influence financial distress. Therefore, the experience of 
2008 Through 2011," J. Account. Financ., vol. 12, no. 1, pp. 31-41, 2012.

the supporting statements, making it take longer to complete audit [22]. Furthermore, the completion of the audit process is performed more often because of the numerous procedures taken during the process. Despite the fact that the samples average was large or long, it was observed to be below the standard limit, while the majority includes those that experience financial distress. This situation was, therefore, not caused by audit delay, as it was not experience.

\section{CONCLUSION}

This research examined and analysed the relationship between external audit factors, encompassing going concern opinion, auditor switching, reputation and delay on financial distress in manufacturing companies within 2014-2017. Furthermore, the study is observed to have implications for company policy in analysing the condition of financial distress.

Based on the results obtained, three independent variables were reported to possess a significant and positive relationship with financial distress, although one other produced an insignificant relationship. Therefore, the influencing variables include going concern opinion, auditor switching and also audit reputation that specifically had a positive regression coefficient that was contrary to the hypothesis. Conversely, it was established that audit delay does not influence financial distress.

This study was faced with certain limitations, including (1) the restriction on the use of manufacturing companies as samples. (2) the constraints of the financial distress measurement include the use of Altman Z score model, and the non-utility of dummy assessments. Further specific research, encompassing the use of dummy assessment and models other than the Altman $\mathrm{Z}$ score model, e.g., the Taffler model and the Zmijewski model, or those adopted during prediction for all studies of accounting that are based on bankruptcy. In addition, subsequent research investigates the influence of other external audits, which possible play a moderating role.

\section{ACKNOWLEDGMENT}

The author is grateful for the financial support of the BPP-DN program obtained from the Ministry of Research and Technology of Higher Education (Ristek Dikti) Indonesia.

\section{REFERENCES}

[1] M. Elmabrok and K.-N. Soon, "Using Altman â€ $€^{\mathrm{TM}}$ s Model and Current Ratio to Assess the Financial Status of Companies Quoted In the Malaysian Stock Exchange," Int. J. Sci. Res. Publ., vol. 2, no. 7, 2012.

[2] L. June, "Prediction of Corporate Bankruptcy from
[3] P. Ghosh, "Testing of Altman 's Z - Score model, a Case Study of Dunlop India Ltd .," Indian J. Res., no. May, pp. 219-220, 2013.

[4] R. R. Gamayuni, "Berbagai Alternatif Model Prediksi Kebangkrutan," J. Akunt. dan Keuang. Indones., vol. 14, no. 1, pp. 75-89, 2009.

[5] K. Mannasoo, P. Maripuu, and A. Hazak, "Investment, Credit, and Corporate Financial Distress: Evidence from Central and Eastern Europe," Emerg. Mark. Financ. Trade, vol. 938, no. August, 2017.

[6] S. Lee, Y. Koh, and K. H. Kang, "International Journal of Hospitality Management Moderating effect of capital intensity on the relationship between leverage and financial distress in the U . S . restaurant industry," Int. J. Hosp. Manag., vol. 30, no. 2, pp. 429-438, 2011.

[7] C. Chen, G. Yen, and F. Chang, "Strategic auditor switch and financial distress prediction - empirical findings from the TSE-listed firms Strategic auditor switch and financial distress prediction - empirical findings from the TSE-listed firms," Appl. Financ. Econ., vol. 19, pp. 59-72, 2009.

[8] G. V. Cenciarelli, G. Grace, and M. Allegrini, "External audit and bankruptcy prediction," J. Manag. Gov., 2018.

[9] P. Dechow, W. Ge, and C. Schrand, "Understanding earnings quality : A review of the proxies, their determinants and their consequences \$, J. Account. Econ., vol. 50, no. 2-3, pp. 344-401, 2010.

[10] S. Balsam et al., "Auditor Industry Specialization and Earnings Quality Summary," Audit. A J. Pract. Theory, pp. 1-46, 2003.

[11] S. A. Mansi, W. F. Maxwell, and D. P. Miller, "Does Auditor Quality and Tenure Matter to Investors? Evidence from the Bond Market," J. Account. Res., vol. 42, no. 4, 2004.

[12] D. Bryan, S. Tiras, and C. Wheatley., "Are Going Concern Opinions Associated with the Reversal of Financial Distress for Bankrupt Firms ?,” 2010.

[13] S. K. Choi and D. C. Jeter, "The effects of * on," J. Account. Econ., vol. 15, pp. 229-247, 1992.

[14] M. A. Geiger, K. Raghunandan, and D. V Rama, "Recent Changes in the Association between Bankruptcies and Prior Audit Opinions," Audit. A J. Pract. Theory, vol. 24, no. 1, pp. 21-35, 2005.

[15] M. A. Geiger, K. Raghunandan, and D. V Rama, "Auditor decision-making in different litigation qualified audit opinions earnings response coefficients 
Account. Res., vol. 22, no. 4, pp. 759-789, 2005.

environments : The Private Securities Litigation Reform Act, audit reports and audit firm size," J. Account. Public Policy, vol. 25, pp. 332-353, 2006.

[16] D. Bryan, T. Janes, and S. L. Tiras, "The Role that Fraud has on Bankruptcy and Bankruptcy Emergence," J. Forensic Investig. Account., vol. 6, no. 2, pp. 126$156,2014$.

[17] B. Bratten, L. M. Gaynor, L. Mcdaniel, and N. R. Montague, "The Audit of Fair Values and Other Estimates: The Effects of Underlying Environmental, Task, and Auditor-Specific Factor," 2013.

[18] A. D. Blay, "Independence Threats, Litigation Risk, and the Auditor's Decision Process," Contemp.
[19] T. Kida, “An Investigation into Auditors â€ $€^{\mathrm{TM}}$ Continuity and Related Qualification Judgments," $J$. Account. Res., vol. 18, no. 2, pp. 506-523, 1980.

[20] K. B. Schwartz and K. Menon, "Switches by Failing Firms," Am. Account. Assoc., vol. 60, no. 2, pp. 248-261, 1985.

[21] B. D. Kluger and D. Shields, "Auditor changes, information quality and bankruptcy prediction," Manag. Decis. Econ., vol. 10, no. 4, pp. 275-282, 1989.

[22] C. Margaretha and S. Suhartono, "Kemampuan Ukuran Perusahaan Memoderasi Determinan Audit Delay," Auditing, vol. 5, no. 2, 2016. 